\title{
Microbuses and Mobile Homemaking in Exile: Sudanese Visiting Strategies in CAIRO $^{1}$
}

\author{
Anita FÁbos
}

\begin{abstract}
Paying home visits to mark social events and maintain networks is an established cultural pattern in Arab countries. Northern Sudanese displaced in Cairo in the 1990 s made significant efforts to continue visiting each other in their temporary homes, despite having to travel long distances to members of their widely scattered networks. The deterioration of the legal and political status of Sudanese living in Egypt during the 199os contributed to longer-term uncertainty for those who sought safety and security in Cairo. In this article, I argue that this long-term uncertainty constitutes a protracted refugee situation, and that Sudanese visiting practices constituted a mobile homemaking strategy that actively contributed to the negotiation of a complex ethnic identity in their protracted exile. Ranging across space and connecting people through experiences and values of Sudanese "homeyness," visiting during these fraught years connected individuals and networks into constellations that recreated familiar patterns of homemaking but also encouraged new meanings granted to homeland and belonging. Woven through the more familiar relationship between "home" and "away" were the policy positions about urban refugees taken by the Egyptian government, United Nations High Commission for Refugees, International Organization for Migration, and other humanitarian aid and resettlement agencies, which produced a state-centred view of "home" for Sudanese.
\end{abstract}

\section{Résumé}

Dans les pays Arabes, rendre une visite à domicile pour commémorer les événements de la vie sociale communautaire, ainsi que pour maintenir les réseaux, fait partie des pratiques culturelles consacrées par l'usage. Les Soudanais $d u$ nord en situation de déplacement au Caire durant les années 90 faisaient des efforts considérables pour continuer de se rendre visite dans leurs domiciles temporaires malgré la nécessité de devoir effectuer de longs trajets pour rejoindre ceux qui faisaient partie de leurs réseaux dispersés. La détérioration du statut juridique et politique des Soudanais résidant en Égypte pendant les années 90 avait contribué à une situation d'incertitude à long terme pour ceux qui cherchaient la sécurité et la stabilité au Caire. Je soutiens dans cet article que cette incertitude marquait les Soudanais comme des réfugiés à long terme. Leurs visites à domicile faisaient ainsi partie d'une stratégie pour établir un domicile en mobilité qui a fortement contribué à composer une identité ethnique complexe dans le contexte de leur exil prolongé. En s'étendant à travers l'espace et reliant ces individus par les expériences et les valeurs de la 'domesticité' soudanaise, le fait de rendre visite à domicile pendant ces années de précarité tissait non seulement des liens entre individus et réseaux, reproduisant ainsi une constellation de motifs connus associés à l'établissement d'un domicile, mais favorisait aussi l'essor de nouvelles significations liées aux notions de patrie et d'appartenance.

CAnita Fábos, 2015. This open-access work is licensed under a Creative Commons Attribution-NonCommercial 4.0 International License, which permits use, reproduction and distribution in any medium for non-commercial purposes, provided the original author(s) are credited and the original publication in Refuge: Canada's Journal on Refugees is cited. 
Entre la dialectique plus familière de «chez soi» et «ailleurs» circulaient les positions politiques vis-à-vis des réfugiés urbains adoptées par le gouvernement égyptien, l'UNHCR, l'OIM, ainsi que d'autres organismes d'aide humanitaire et de réinstallation, qui avaient crée une idée de «domicile» chez les Soudanais axée sur l'état.

\section{Introduction}

$\mathrm{M}$ y Sudanese friend Khalda lives near the end of the Ma'adi-El Marg line in 'Ain Shams. The Metro, completed in 1989, had cut her 90-minute commuting time to her downtown Cairo job in half.

One afternoon, I met up with Khalda as she was leaving the office. "I told Majdy that I would stop by for a visit later," she said.

"Will we still go to visit Samira this afternoon?" I asked.

"Yes," she assured me, "but I have to be home early because Fatima's mother is sick and I have to pass by."

We set off on foot to the nearby Sudanese Victims of Torture Group office for a quick visit with Khalda's activist friends, then hopped on the Metro for two stops to the Ramsis station, where we boarded a Toyota microbus, waited for it to fill up with passengers, and set off through the late afternoon traffic to the suburb of Nasr City. An hour or more of slow going in the summer heat brought us to the refugee family we had planned to visit. Khalda's long day would end after several more social calls in her own neighbourhood, another hour away by microbus.

Khalda's visits that day in 1996 encompassed three discrete and far-flung neighbourhoods in Cairo, then home to some 15 million residents and including a rapidly growing number of forced migrants seeking safety and security from the hard-line Islamist government in Khartoum. The time Khalda spent traversing the city on public transportation far exceeded the short visits with the various people in her interlocking social networks. An unmarried secretary in her mid-twenties, Khalda had fewer and different social obligations compared with those of married women with children or her male counterparts, but still spent a good deal of her free time calling on other Sudanese. Sudanese in Cairo have seen their social networks expand from a previous focus on kin and neighbours to include sets of colleagues old and new, acquaintances and fellow activists from Cairo's burgeoning NGO movement, and the relatives and friends of these individuals, most moving to and through Cairo seeking asylum, medical treatment, or temporary escape from the oppressive political climate back home. With high levels of unemployment and depression in the community, most Sudanese in my study found solace, mutual aid, and entertainment through social visits and were prepared to travel long distances to achieve these benefits.
For people forced to live in an unfamiliar setting for an indeterminate length of time, home may take on a heightened meaning, as if experienced for the first time in the breach. Yet, as Brun and Fábos ${ }^{2}$ note, home for forced migrants in protracted conditions of displacement is both contextual and fluid, experienced individually and socially, and connects local, national, and political dimensions. For Sudanese exiles, Cairo in the 1990 became a canvas for a particular set of notions about home that were as ephemeral as they were tied to long-standing historical identities. The Republic of Sudan, carved out of Greater Egypt in the twentieth century, had provided "Sudanese" a sense of national homeland for a relatively short time; identities shared with Egyptians, such as "Arab" and "Muslim," fellow anti-colonial independence fighter, and "brother" in an ancient Nile Valley civilization endured. But "home" for Sudanese in Cairo was also connected to particular Sudanese ways of being and doing, of a moral world view that provided Sudanese Arab Muslims with a distinctive ethos. In the 1990s, this ethos was to be challenged by a rapidly developing political and economic crisis that required Sudanese to make frightening choices on staying in Egypt or seeking even less familiar alternatives, and postponing indefinitely any "return" to the dusty streets and low-slung dwellings of northern Sudan.

I have argued elsewhere 3 that Sudanese in Cairo, during the politically uncertain 1990s, nurtured an identity that enabled them to participate in Egypt's official "brotherhood" discourse while cultivating a private Sudanese ethnicity based on what they determined to be their superior propriety in Muslim and Arab norms of behaviour. Publicly, Sudanese were "at home" in Cairo, while privately they lamented the poor manners of the Egyptians, so different from "back home." The official fiction that Sudanese were "at home" in Egypt had the all-too-real effect of voiding the possibility of the international community addressing their predicament by finding Sudanese resettlement possibilities in a new national home. The particular "constellation of home" 4 that emerged for Sudanese was a contested one, with Sudanese conceptions of domestic and territorial unfamiliarity loudly overruled by Egyptian insistence that "brothers" could never be "guests" in their own home.

The deterioration of the legal and political status of Sudanese living in Egypt during the 1990s contributed to longer-term uncertainty for those who sought safety and security in Cairo. Sudanese visiting practices helped to maintain networks of mutual support and identity for people living in increasingly protracted, precarious circumstances; furthermore, visiting constituted a mobile homemaking strategy that actively contributed to the negotiation of a complex ethnic identity in protracted exile. Ranging

(C)Anita Fábos, 2015. This open-access work is licensed under a Creative Commons Attribution-NonCommercial 4.0 International License, which permits use, reproduction and distribution in any medium for non-commercial purposes, provided the original author(s) are credited and the original publication in Refuge: Canada's Journal on Refugees is cited. 
across space and connecting people through experiences and values of Sudanese "homeyness," visiting during these fraught years connected individuals and networks into constellations that recreated familiar patterns of homemaking but also encouraged new meanings granted to homeland and belonging. Woven through the more familiar relationship between "home" and "away" were the policy positions about urban refugees taken by the Egyptian government, UNHCR, International Organisation for Migration, and other humanitarian aid and resettlement agencies, which produced an additional dimension of "home."

The ethnographic inquiry from which this smaller study is drawn was conducted between 1994 to 1999 as part of my doctoral and post-doctoral research among Cairo's Arabic-speaking northern Sudanese-identified denizens. This period was momentous for government reprisals on Sudanese living in Egypt following the 1995 presidential assassination attempt, reputedly by Sudanese operatives, which in my view triggered a shift in Sudanese experiences of belonging. During that time, I spent time with dozens of Sudanese families and individuals in varied settingsprivate homes, offices, cultural events, educational institutions-and participated in numerous discussions with Sudanese, Egyptian, and other colleagues to explore the unique characteristics of Cairo as a site of sanctuary for political exiles from Sudan, and the role of the Egyptian state in offering legal refuge. Names and identifying details for all of my research participants have been changed for confidentiality and to reflect the real risks associated with living as a Sudanese forced migrant in Egypt. My positioning as a Euro-American, Arabic-speaking woman married to a Sudanese businessman undoubtedly shaped my community access and understanding. My own recollections of trips to visit Sudanese friends across Cairo-the visceral experience of sitting crammed in among fellow microbus passengers, feeling the runnels of sweat under my clothing, and tossing with the movement of the driver's multiple stops and startsbrought home the sheer physical discomfort involved in paying social calls. I propose that Sudanese exiles were willing to travel long distances to visit their fellow Sudanese as a strategy for coping with their protracted liminal circumstances of exile, and that this strategy constituted mobile homemaking and contributed to a particular ethnic identity.

\section{Cairo as a Protracted Refugee Situation: Protracted Circumstances for Urban Forced Migrants}

The use of the policy term protracted refugee situations (PRS) to describe long-term circumstances of displacement for people fleeing conflict first came into widespread use in the new millennium, although the UNHCR and other organizations had previously managed humanitarian caseloads resistant to "solutions" as early as the Second World War. The protracted existence of refugee camps where humanitarian assistance is available and residence is considered, at least theoretically, as "temporary" does not preclude occupants from leaving; indeed, a percentage of "immobilized" encamped refugees are always on the move seeking work, education, and marriage partners, or simply a way out; these movers are, additionally, a part of urbanization flows and processes that include nationals and border-crossers, both voluntary and coerced. Thus, urban areas in the global South are absorbing not only labour migrants from rural areas, but also internally displaced migrants, border-crossing refugees, and a host of others with variable legal statuses. 5

There is growing recognition that people "out of place" living in urban areas experience many of the same conditions of "permanent temporariness" as do encamped refugees in protracted refugee situations. As the UNHCR points out, "Long-staying urban refugees are not typically included in an understanding of protracted refugee situations. Yet tens of thousands live clandestinely in urban areas, avoiding contact with the authorities and bereft of legal status." These "urban forced migrants" are often ineligible for government services and, if "unregistered," are unable to access humanitarian relief, and from the perspective of regulation, remain largely an "invisible" population.7 With few resources and tenuous legal status, these women and men-and their undocumented children-have few options for addressing their temporary circumstances. Furthermore, the pan-Arab discourse regarding forced migrants from neighbouring countries, which combines notions of Arab hospitality with Islamic concepts of sanctuary, has resulted in "guest" policies that produce ambiguous "permanent" temporary residence while limiting access to services and protection. ${ }^{8}$ The long-standing populations of forced migrants living in Cairo, in addition to Sudanese, include Palestinians, ${ }^{9}$ Eritreans and Ethiopians, ${ }^{10}$ Somalis, ${ }^{11}$ and more recently, Iraqis. ${ }^{12}$ Sudanese nationals from a variety of ethnic and religious groups make up one of the largest populations of urban forced migrants in Cairo. ${ }^{13}$

Egyptian immigration and international refugee policies have shifted over time according to local or domestic political circumstances, global conditions for mobility, and organizational responses. ${ }^{14}$ Migrants and "foreigners" have been regulated differently according to their nationality; receiving any international recognition of asylum status is thus highly dependent on the political moment and relations between their national government and the state of Egypt. For example, Egypt granted Palestinians virtually the same rights as Egyptian nationals in the 1970s, including access to national health care, education, and jobs, only to rescind

CAnita Fábos, 2015. This open-access work is licensed under a Creative Commons Attribution-NonCommercial 4.0 International License, which permits use, reproduction and distribution in any medium for non-commercial purposes, provided the original author(s) are credited and the original publication in Refuge: Canada's Journal on Refugees is cited. 
this status in 1972 following the events of Black September in Jordan. Sudanese moving in and out of Egyptian territory have seen their residency rights and requirements for border crossing change over the last 50 years, sometimes dramatically. While the 1982 Integration Agreement did away with the need to show passports at the Egypt-Sudan border, ${ }^{15}$ this residency permission was rescinded after the 1996 UN Security Council sanctions against Sudan following the 1995 Islamist attack of the Egyptian president. Sudanese already in Egypt experienced harassment, arrest, and occasionally deportation, and Sudanese aircraft were denied rights to Egyptian airspace. ${ }^{16}$

Excluded from both domestic citizenship and international recognition as refugees, Sudanese participants in my study were obliged to navigate an ambiguous and uncertain policy environment. Their protracted uncertainty shaped their ability to feel "at home" and to be able to "make home" in Egypt in specific ways for at least a decade. The UNHCR office in Egypt only rarely granted refugee status to Sudanese nationals living in Egypt, citing the residential and other benefits provided by the 1982 Integration Agreement between the two nations. Even though Sudanese began to flee to Egypt in the thousands following the 1989 Islamist coup in Sudan, for the six years until the 1995 abrogation of residency rights the increasingly desperate Sudanese forced migrants could not claim asylum in any meaningful way. ${ }^{17}$ And, as a result of the Egyptian government's "Unity of the Nile Valley" language promoting the notion that Sudanese were "at home" in Egypt as "brothers of the same mother," the grim economic conditions and legal limbo experienced by Sudanese endured. Finally, while the door to receiving international refugee status did indeed open after 1995, the official Egyptian discourse of "brotherhood" did not significantly change, and the Sudanese response to their circumstances remained ambiguous. Thus, the first part of my argument for this article is that conditions for Sudanese over most of the decade can be usefully analyzed as a "protracted refugee situation," despite the absence of an encampment policy and perhaps as a result of an international inability to address the humanitarian concerns of thousands of people "out of place" in an urban environment. In the following section, I describe the particular liminal positionality for Sudanese forced migrants in Cairo, both legally and culturally, that has shaped a strategy of mobile homemaking.

\section{Cairo as "Border Zone": Urban Life, Liminality, and Mobility for Sudanese Refugees}

Even in the mid-199os, Cairo was considered a "megacity." The metropolitan area of Cairo proper spans 453 square kilometres, and including the urbanized outskirts is currently home to more than 18 million people. ${ }^{18}$ While in-migration is no longer the prime reason for Cairo's continued population growth and expansion, it is still a destination and hub for Egyptians, especially young people, from rural and provincial areas, as well as for people on the move mainly from conflict zones in the Middle East and Africa. ${ }^{19}$ Cairo's varied urbanscapes range from the faded elegance of wust al-balad (downtown) and the island neighbourhood of Zamalek, industrial working-class areas like Imbaba and Shubra, once-rural villages sprouting apartment buildings alongside fields of barsoum (alfalfa), vast residential zones such as Nasr City that have sprung up along the city's ring road, squatter areas and other informal settlements built up by newcomers on the margins of more established neighbourhoods, and gated communities with names like Dreamland for the super-rich. ${ }^{20}$

Urban life in Cairo is characterized by huge disparities of wealth and opportunity. With one of the highest urban densities in the world, Cairo's population is mostly young and largely poor, ${ }^{21}$ and lives in rickety concrete-and-brick multi-family apartment blocks stretching far into the dusty horizon. Egypt's incorporation into neoliberal global networks of finance, and subsequent attempts by Washington to shape economic growth through structural adjustment policies and massive aid packages are rendered visible through the rapid rise of five-star hotels, residential developments for military officers, private hospitals, and suburban shopping malls, all served by a vast network of newly built elevated roads, underground sewer and water systems, and the ongoing expansion of the Cairo Metro. The general public has limited or controlled access to open space: public places like plazas, parks, mosques, or museum complexes are managed in different ways, such as ticketing, security guards, and surveillance, ${ }^{22}$ while wealthier Cairenes socialize at members-only sporting clubs in specific neighbourhoods.

In the 1990s, Sudanese from all socio-economic levels were present in Cairo. During his 15 years of exile in Egypt, former Sudanese military ruler and president Jaafar Al-Nimeiri resided in a splendid villa in Heliopolis. Other wealthy and connected Sudanese, such as Sudan's last democratically elected president Sadiq al-Mahdi, lived in grand apartments in Cairo's more exclusive neighbourhoods, such as Heliopolis or Zamalek. Many urban professionals also left Sudan for political reasons at that time, and bought, or more commonly rented, apartments in middleclass areas such as Mohandiseen and Maadi. Those fleeing with fewer resources or from humble backgrounds found themselves dingy accommodations in rundown buildings downtown or cheap apartments sprinkled among newer blocks. Some, with relatives who had previously emigrated to Egypt in the 1940s when Sudanese were being recruited for posts connected with the military, rented rooms among

(C)Anita Fábos, 2015. This open-access work is licensed under a Creative Commons Attribution-NonCommercial 4.0 International License, which permits use, reproduction and distribution in any medium for non-commercial purposes, provided the original author(s) are credited and the original publication in Refuge: Canada's Journal on Refugees is cited. 
these long-standing clusters of Sudanese families in 'Ain Shams and Abbasiyya. While Sudanese did congregate in certain areas across the city, the tens of thousands of refugees $^{23}$ arriving after the 1989 coup were distributed broadly and unevenly among Cairo's restless millions.

Cairo-also known by the charming moniker Umm al-Dunya (Mother of the World) - is a cosmopolitan city shaped over several millennia, and its residents and their religious, cultural, and linguistic heritage reflect multiple conquests and migrations. Nubian, Ismaili, Coptic, Mamluk, and European identities have been variously blurred or revealed by historical processes. ${ }^{24}$ In the 1990 , the Egyptian state managed Cairo's multicultural denizens according to a number of binaries: Egyptian/foreigner, Muslim/Christian, citizen/refugee, and a few others. Specific state policies whereby "foreigners" and "nationals" paid differential prices for housing and schooling, as well as for hotels and tourist attractions, helped to establish these boundaries among locals, reinforced by Egyptian media coverage of foreigners. As a Muslim state, Egypt also separated Muslim and Christian legal as well as religious identities with policies that managed the Christian minority through employment quotas and limited church building permits; the state additionally stands accused of turning a blind eye to anti-Christian violence. ${ }^{25}$ The citizen/refugee distinction emerged in the twentieth century as a function of the nation-state system's management of civilians displaced across borders by war. Egypt, an original signatory of the 1951 Geneva Convention for the Protection of Refugees, has provided political asylum and refugee status for decades, but with reservations that limit rights. Additionally Egyptian immigration law does not grant the possibility of naturalization, ${ }^{26}$ and so refugees are essentially regulated as foreigners for as long as they reside in Egypt.

Cairo's dynamic mixture of cultures cannot, of course, be completely brought into order by these regulatory categories, and Muslim Arab Sudanese in particular inhabited an ambiguous space in the national imagination of Egypt. Even after the unilateral abrogation of the Integration Agreement in 1988 by president Sadiq al-Mahdi of Sudan, Sudanese in Egypt continued to be treated as quasi-citizens, with full access to national education, health care, and employment. As fellow Arabs and Muslims, furthermore, with many mutual ties and shared history of colonialism ${ }^{27}$ and regional struggles for independence, Sudanese in Egypt largely felt "at home," even after it became politically impossible for most to return to Sudan after the Islamists came to power. Even after the Egyptian government's 1995 crackdown on Sudanese residents, Sudanese took to the streets to demonstrate in solidarity with their Egyptian "brothers."
Neither party fully accepted the notion that Sudanese were foreigners in Egypt. Refugee status, an internationally recognized legal category, is predicated upon a person's need to seek protection from another state in the event that one's own state is unable or unwilling to provide it. Arguing that Sudanese in Egypt inhabited a special legal category, the UNHCR was not authorized by the Egyptian government to regularly process Sudanese for refugee status until 1994. ${ }^{28}$

Muslim Arab Sudanese during this period thus inhabited a liminal position-culturally as well as legally. As uncertainty and anxiety among Sudanese in Cairo grew, a subtle counter-narrative to the official "brothers in a united Nile Valley" discourse emerged that quietly asserted a distinct Sudanese identity on the basis of moral behaviour. When Sudanese in Cairo experienced the collective punishment of the Egyptian state after 1995, the feeling of alienation grew and the need for solace and solidarity with fellow Sudanese in exile seemed to increase. Yet even as a new form of ethnicity emerged, Sudanese were reluctant to distinguish themselves completely from their Egyptian hosts, choosing as boundary markers attainable qualities like hospitality, generosity, and modesty. This ambiguous ethnicity, I have argued elsewhere, stemmed from the uniquely liminal position Sudanese inhabited in the 1990s. ${ }^{29}$

While Muslim Arab Sudanese in the "greater Nile Valley" were between belonging and foreignness for historical reasons, and between citizenship and refugeeness as a function of immigration policy, Cairo was also a place of restlessness, struggle, and agency. The liminal category occupied by Sudanese, and the protracted nature of their predicament nevertheless did not prevent them from actively strategizing to improve their circumstances. Cairo, one of the major hubs for information, travel, international organizations, and financial networks in the region, served as a critical border zone for Sudanese. Cairo was a place to wait while a work visa to Bahrain, Qatar, or Saudi Arabia was arranged. It was the headquarters of the UNHCR, which had begun refugee-status determination and-for a fraction of Sudanese-a process of resettlement to North America, Europe, or Australia. Cairo was also a thriving marriage market for Sudanese hoping to find partners with attractive prospects beyond Egyptian borders. Sudanese in the 1990 s were stuck in a policy limbo that challenged previous assertions of brotherhood and undermined the notion of Egypt as a second "home." Nevertheless, Cairo became a significant confluence of Sudanese mobilities, both real and aspirational. Fellow members of their community of exiles comprised the most significant network of support, help, information, and solace. Visiting each other's households was a major daily activity for many Sudanese. In the

CAnita Fábos, 2015. This open-access work is licensed under a Creative Commons Attribution-NonCommercial 4.0 International License, which permits use, reproduction and distribution in any medium for non-commercial purposes, provided the original author(s) are credited and the original publication in Refuge: Canada's Journal on Refugees is cited. 
following section, I outline the second part of my argumentthat Sudanese visiting practices became a type of mobile homemaking in uncertain, temporary circumstances.

\section{An Uncertain "Home": Temporary Visiting Patterns and Mobile Social Networks}

Visiting to mark social events and maintain networks is an established cultural pattern in Arab countries. The ethnographic literature of the Middle East is rich with examples of visiting strategies that enable women and men to access information, status, and resources through networks that include both kin and non-kin. A cursory look at anthropologists writing on urban Sudanese visiting patterns exemplifies the degree to which group strategies, while drawing upon Sudanese cultural norms and ideals, are shaped by local and time-specific circumstances. Salem-Murdoch ${ }^{30}$ describes the ways in which farmers resettled on an agricultural scheme built up access to resources such as water and other agricultural inputs by cultivating social networks in creative ways. Ismail's qualitative analysis of women's visiting patterns in urban Sudanese settings points to chan ges in whom a woman visits, depending on the degree of urbanization. ${ }^{31}$ After close kin visits, she found that women in Khartoum gave priority to visiting female friends compared to their sisters in provincial towns, who tended to visit neighbours more frequently.

Anthropologists have observed that visiting strategies may serve as cultural metaphors, the analysis of which illuminates processes of social change. For instance, Eickelman's article $^{32}$ examining visiting patterns of Omani women in a provincial oasis town describes a gendered strategy that links birth-giving to the accumulation of social capital, producing in its wake significant demographic change. In this context, the metaphor of desirable fecundity points to a deeper need for women to connect with one another to exchange crucial information during a time of dramatic social and economic transformation. The act of giving birth, then, enables women to receive and pay social calls, in the process strategizing over how to enhance status and build critical links in their changing social world.

In Cairo, both Egyptian and Sudanese residents from a range of socio-economic classes acknowledge the social obligation to pay visits to individuals with new babies, to those who are travelling or returning from travel, or who are ill or bereaved. We should not discount the pleasure of spending time in the company of one's relatives or friends as a reason for visiting. There are also set events in the Islamic ritual calendar where Egyptian and Sudanese Muslims visit a wide network of people, and a corresponding calendar for the smaller number of Egyptian and Sudanese Copts in both countries. Judging from my own research, Sudanese visiting patterns in Cairo have broadened beyond visits to family members and neighbours to include cross-gender visits to friends and colleagues (though at the office, not at home) and hafalat al-wada'a (goodbye parties), which may draw a wide variety of people across kin, professional, and political groups. For example, at a goodbye lunch at the house of a work colleague, Zein-a Sudanese exile leaving for a resettlement place in the United States-was toasted by family left behind, members of his religious brotherhood, a Coptic businessman, and two anthropologists.

However, since the tremendous influx of Sudanese forced migrants to Egypt in the mid- and late nineties, visiting as a Sudanese social activity took on a new dimension that explicitly related the type, frequency, and physical distance over which visiting networks extended to Sudanese ethnic identity in Egypt. The uncertainty that faced Sudanese in protracted exile in Cairo and the context-specific discourse of "home" in Egypt rendered their homemaking practices mobile, fluid, and ephemeral. And, in a subtle response to Egyptian declarations of solidarity and acceptance, Sudanese expressed their moral superiority and hence separate identity within the larger Cairene society of which they are part through visiting strategies that emphasized the duty to remain connected to family and friends despite the great difficulty in doing so.

\section{Mobility and Mobile Social Networks}

Cairo is a bustling and crowded city, and while there are many options for moving from one place to another, congestion, noise, and pollution make getting around slow and unpleasant for most residents. Transportation is stratified, with middle- and upper-class car-owners jostling for space on congested streets with taxis, buses, motorcycles, bicycles, and the occasional horse- or donkey-drawn cart. The majority of residents rely on an extensive public/private transportation system to get around;33 public buses are the cheapest option and are crowded and noisy, while the Cairo Metro and a network of private microbuses cost more but offer riders somewhat more comfort, at least after rush hour. The incessant hum of traffic is punctuated loudly and often by car horns blaring their warning. Routes are often snarled with traffic jams, provoking outbursts among short-tempered drivers. For most Cairenes, getting around the city is stressful and exasperating.

Sudanese exiles adapted to their Cairo surroundings, despite nostalgic comparisons between their spacious compounds back home and the cramped Cairo high-rises where their apartments were located. As newcomers, they learned to negotiate the often long distances between their apartments and those of their relatives and friends. These trips could involve any number of types of public transportation,

(C)Anita Fábos, 2015. This open-access work is licensed under a Creative Commons Attribution-NonCommercial 4.0 International License, which permits use, reproduction and distribution in any medium for non-commercial purposes, provided the original author(s) are credited and the original publication in Refuge: Canada's Journal on Refugees is cited. 
each with a different set of practical problems and unspoken rules. Cairo's underground rapid transit, the Metro, required newcomers to make a quick mental map of the stations in relation to the random pattern of Sudanese residences, and to learn a bewildering variety of intermediary conveyances between points of exit from the Metro and the local address of the object of their visit. These might include one or more of the following modes of transport: public buses, where a cheap ticket would pay for an unsettlingly crowded ride; private microbuses that guaranteed every passenger a seat but made money for their owners by racing through their routes at breakneck speed and screeching to a halt for potential passengers who flagged them down on the roadside; street taxis that cost ten times the amount of a microbus ticket but provided door-to-door service; and sometimes unlicensed taxis that provided short-distance shuttle service. Sudanese on their visiting rounds might make a dozen small trips across several modes of transport.

Sudanese visiting mobilities took a variety of forms that were furthermore shaped by gender expectations and class differences. People-mostly men-would walk from one visit to the next largely if those they were visiting were located in downtown Cairo, for several possible gendered reasons. According to my research, educated Sudanese men in exile in Egypt had particular difficulties reconstituting a livelihood, and downtown Cairo was a key neighbourhood where clusters of single Sudanese men could find cheaper apartments or even hotel rooms, and connect with other men in a similar predicament. Downtown Cairo was also the site of a significant level of Sudanese NGO activity, and many exiled men made the rounds of these small, dingy rented spaces to visit and drink tea with luckier men (and occasionally women) who worked there. It was not as common for Sudanese women in exile with time on their hands to visit colleagues or friends at their offices, and less acceptable for them to walk around in downtown Cairo. While public space in Cairo was by no means closed to women outright, women's inhabiting of that space was fraught with social and physical hazards, from attracting comment or even punishment for supposed transgressions of moral boundaries to sexual and racial harassment. Women thus more commonly used mechanized transport to get around, and-as a side effect of gendered norms of beauty and adornment-might wear elegant footwear that in any case would have made walking slow or uncomfortable for them.

While most Sudanese in Cairo visited daily, these visits varied greatly by occasion and purpose-and shaped the extent of people's range quite dramatically from day to day. Both men and women visited family members and close friends most frequently, and to my understanding tried to rent apartments close by (i.e., accessible by one mode of transport). More striking than the maintenance of kin networks through visiting was the degree to which Sudanese exiles made social calls to people less familiar to them. Although social connections by definition did exist-one might pay a visit to a university friend's sister or uncle, for example, or include acquaintances met at a friend's house in another round of visits-I was intrigued by the fluid, ephemeral quality of visiting patterns. As new Sudanese exiles arrived in the city, and others sought work in the Gulf or found opportunities to travel to the West, the visiting networks of which they were temporarily part shifted and altered to accommodate different people living in different places.

What endured across this landscape of kaleidoscopic connections was a distinctly Muslim Arab Sudanese sense of home in exile. Mobile visiting strategies in Cairo in the 1990 s became a key feature of Sudanese social life and identity. The time and effort that was spent by Sudanese in maintaining and pursuing social networks through visiting one another is one of several metaphors used by Sudanese to highlight differences between their communities in Cairo and those of their Egyptian hosts. And, although my research participants did not emphasize the material aspects of Sudanese domestic space in exile per se, they did make frequent note of what they considered the "un-Sudanese" enthusiasm for material possessions demonstrated by Egyptian neighbours and friends.

Zeinab, a middle-aged professional Sudanese woman, described a visit to an Egyptian colleague, during which the colleague drew Zeinab's attention to one expensive item after another. As part of a generalized process of boundarymarking that set Sudanese propriety against an Egyptian "lack of manners," Zeinab made it clear to me that Sudanese did not mark their status through possessions as did Egyptians, thus bringing them closer to the Muslim Arab ideal of modesty. Hospitality to visitors by Sudanese exiles with little to spare was also presented as a significant difference between themselves and their Egyptian hosts. Karim, a young married political exile, told me that his apartment had never been empty of visitors over the four years he had been residing in Cairo. "They just call from the airport and say, 'We are here,' and then you go and pick them up," he said. The claim that Sudanese are generous and welcoming hosts-another Muslim Arab ideal-was contrasted with a purported Egyptian standard of putting up their relatives in a hotel. "Egyptians," asserted a young Sudanese woman, a medical doctor, "love their country but don't care for one another, while Sudanese love one another, but don't care for their country."

The reality is more complex than this ideal portrays. While these examples illustrate a discourse of placing

CAnita Fábos, 2015. This open-access work is licensed under a Creative Commons Attribution-NonCommercial 4.0 International License, which permits use, reproduction and distribution in any medium for non-commercial purposes, provided the original author(s) are credited and the original publication in Refuge: Canada's Journal on Refugees is cited. 
responsibilities to people ahead of accumulating material possessions, one could also argue that Sudanese, living in rented accommodations and struggling to make ends meet during their extended exile, simply did not have the wherewithal to focus attention and resources on their domestic surroundings. I heard complaints about individuals who had overlooked social obligations to bereaved families, or who visited friends only when they needed a favour. Furthermore, because of the ever-changing quality of social networks due to the mobility of northern Sudanese individuals, people might maintain visiting patterns for a few months only, either moving on themselves or having to replace friends and relatives in their visiting rounds with other people.

However, the obvious need to stay in touch with people in a community increasingly fragmented by urban sprawl, labour migration, and resettlement opportunities only partially explains why visiting played such a central role in Sudanese identity discourse in 1990s Cairo. The Sudanese portrayal of themselves as having a strong sense of obligation to visit visà-vis Egyptians became one aspect of an identity discourse that uses shared cultural patterns to redefine Sudanese subordinate status in the eyes of their hosts. By calling on Arab and Islamic meta-narratives that involve Egyptians as kin of equal, or lesser, standing, Sudanese reproach Egyptians for what they see as a weak sense of social duty in the larger Arab context and thus redefine and contest their own marginal role in Egyptian society.

\section{Visiting as Homemaking}

The domestic and community life of Sudanese exiles in Cairo in the 1990 s was characterized by the heightened importance of paying social visits to a wide range of fellow Sudanese displaced by Sudan's ongoing crisis and rendered "temporary" by Egyptian immigration policy. While receiving visitors in their temporary dwellings was sig nificant, I propose that the fluid and dynamic practice of carrying out social visits itself was the key means by which Sudanese made and remade home in Cairo. The day-to-day acts of visiting performed by Sudanese, I suggest, were not only a pragmatic and comforting strategy for members of Sudanese networks, but additionally knitted together individual dwellings across space to produce a Home ${ }^{34}$ in exile for Sudanese in Cairo.

In addition to accompanying my research participants on their frequent visiting excursions across Cairo to visit friends and family members in the Sudanese community, I had the privilege of being welcomed hundreds of times into their dwellings to drink tea or share a meal. Most lived in rented apartments, furnished with cheap living room sets and cast-off tables and chairs by landlords who charged a premium to their Sudanese tenants according to Egypt's
"Foreigners Law."35 Big suitcases used for storage and perhaps standing by for the next opportunity for travel, could be seen in almost every apartment resting on the tops of beat-up wardrobes. Available apartments were not necessarily located in the same neighbourhood, and it was not particularly common for Sudanese to live in close proximity to the people who were significant in their social networks.

Sudanese hospitality to visiting guests was a paramount feature of exile homemaking in Cairo, even if the physical aspects of Sudanese domestic spaces were not particularly extolled. Symbolically, Sudanese hosts made their small, dim, rented accommodations homey through performing acts associated with Sudanese culture and identity. In Sudan, homes are perfumed by casting a few oily sticks of sandalwood or other fragrances (bukhuur) onto charcoal embers, and the scent wafts through the rooms. Sudanese living temporarily in Cairo apartments reproduce this homey smell, more often using electric incense burners acquired from relatives in Gulf countries. ${ }^{36}$ Visitors are offered sweetened milky tea, sometimes flavoured with cloves, cardamom, and cinnamon, and biscuits-in elegant serving sets for wealthier Sudanese exiles, and in glasses on plastic trays for those of more limited resources. Milky spiced tea is a comforting and characteristic of a Sudanese way of consuming tea. While Egyptians also welcome their guests with tea and biscuits, it is unusual for Egyptians to take tea with milk, let alone spices.

Like the Egyptians from whom they rented, Sudanese in exile always maintained a public space in close proximity to the front door to receive visitors. In smaller apartments, a front room might serve double duty as a space for visitors, as well as for dining or sleeping, whereas Sudanese with resources might rent or own a grander apartment with a front parlour set aside solely for receiving guests. I don't recall particular attention being drawn to the dwellings themselves. Rather, we would be greeted at the door by one or more of the residents-with reserved handshakes and greetings if the visitor was unknown, and with an extended welcome of shoulder-touching, hugging, hand-clasping, and lengthy and effusive salutations for closer friends or those met after a long while. Upon moving into the visiting space, it was common for visitors to greet each of the other guests individually, with newcomers moving around the circle of visitors similarly exchanging handshakes or hugs, depending on the closeness of the relationship. Occasionally a person would indicate a reluctance to exchange a physical greeting with a member of the opposite sex, by which it was understood that his or her interpretation of Islamic teachings proscribed such contact between unrelated men and women.

Typically, social visits took place in the afternoon and evening hours, although my companions and I were

CAnita Fábos, 2015. This open-access work is licensed under a Creative Commons Attribution-NonCommercial 4.0 International License, which permits use, reproduction and distribution in any medium for non-commercial purposes, provided the original author(s) are credited and the original publication in Refuge: Canada's Journal on Refugees is cited. 
frequently invited to people's homes to join them as lunch guests as well. Milky tea with lots of sugar, and sometimes biscuits, cake, or Egyptian sweets would be brought outin a family dwelling perhaps by a married woman or her daughter, niece, or another friend, but perhaps by a young husband, or in an office setting, by any one of a number of men playing host. My field notes mention an occasion where, during a visit to a colleague, Salah, whose wife and children had recently arrived from Sudan, Salah's wife requested an unrelated male visitor to bring out a bowl of mulukhiiya ${ }^{37}$ and another of rice, even though she was available to wait on guests. This example of fluid gender responsibilities was not uncommon in my experience, even though it fell outside the stated norms of Sudanese gender roles. Visitors would come and go; my own visits would range from 15 minutes (where I and my companions might wave away tea or sit for only a few minutes, staying long enough to exchange greetings before we made our way to the door escorted by the host) to a few hours. In some cases, a family might urge a young woman to stay the night if her place of residence was far away. Upon departure, in most cases a Sudanese host-whether a man or a woman-would accompany a guest out of the apartment to the door of the elevator, and on occasion all the way down to the street to say goodbye. When I queried Sudanese about this practice, I was told that a proper send-off was characteristic of Sudanese hospitality and, I was asked to note, not shared by Egyptian neighbours. Proper hosting of visitors, I came to understand, was part of a range of acts and comportment linked to a unique Sudanese sense of identity, self-consciously being promoted in Cairo.

On longer visits, hosts might chat with us about the comings and goings of Sudanese in our shared network-who had just come from Sudan, who was leaving on a work contract, the status of someone's resettlement claim. With more intimate relationships, conversations fluttered around news and analyses of our friends' and neighbours' marriage options, family crises, work, study, or project opportunities, and always politics. Conversations often led to plans for further visits. At one such gathering at the house of Abd alFattah and Laila, key figures in the Republican Brothers, ${ }^{38}$ Amani learned that Laila's sister and young nephew would soon be traveling to Canada to join her husband there through a refugee family reunion program. After a discussion of whether woollen sweaters and jeans would be sufficient for the weather there in January, Amani promised that she would make sure to visit her before her imminent departure. During this particular evening, other visitors, mostly exiled Republican Brothers and Sisters, came and went from the apartment. Later, Abd al-Fattah changed from his Sudanese jallabiiya ${ }^{39}$ to shirt and trousers and left for an evening course at a local institute, while Laila's sister and an older female relative put on white tobes $4^{40}$ to go out and do a bit of shopping, even while new visitors arrived. The fluid movement of visitors into and out of Abd al-Fattah and Laila's apartment, as well as the relaxed hosting responsibilities, would certainly have been familiar to Muslim Arab Sudanese from their social milieu back home in Sudan. Specific to the Cairo exile context, though, was a heightened awareness of visiting itself as particularly Sudanese. The overall importance of hospitality and the social ritual joining hosts and guests did lend their temporary dwellings-in-exile a Sudanese homeyness. I further posit that the networks of Sudanese traversing Cairo to participate in everyday acts of visiting created a community-in-exile that approximated a national Home in Egypt. And, in contrast to some of the ethnographic literature on the importance of visiting in nurturing mutual connections, the often impulsive, individual acts of visiting performed by exiled Sudanese in Cairo seemed to be less related to fulfilling social ideals of reciprocity than to collectively reminding themselves of their Home in Sudan and their communal identity.

Taking a mobilities perspective towards Sudanese homemaking practices in Cairo allows us to consider not only the visiting activities that took place in the concrete space of Sudanese apartments but additionally the interaction between Sudanese in motion across urban space. The volatile, ephemeral visiting networks that connected mobile Sudanese and their temporary dwellings in Cairo, I argue, are as much a function of homemaking as burning incense or providing familiar foods for visiting guests. Including mobile social practices such as visiting in our understanding of homemaking helps to theorize the creative agency of people in motion, and to recognize their contributions to reimagining home in exile.

\section{Conclusion}

Cairo continues to be an important node in the Muslim Arab Sudanese diaspora, now spanning towns and cities worldwide in a rebuke to Sudan's inhospitable political climate. The Sudanese who are part of these networks now weave a Sudanese diaspora identity on a global scale through travel shaped by kin networks and family reunification policies, asylum-seeking and job opportunities, and collegiality and established Sudanese communities. Though complicated by variable immigration policies, an ideal of a national Sudanese homeland continues to be present in cultural and social practices, the sending of remittances "back home" and exile politics. Further to Muslim Arab Sudanese maintaining their own national identity, the international system continues to collect statistics on Sudanese nationals, some of whom identify as part of the Sudanese Muslim

CAnita Fábos, 2015. This open-access work is licensed under a Creative Commons Attribution-NonCommercial 4.0 International License, which permits use, reproduction and distribution in any medium for non-commercial purposes, provided the original author(s) are credited and the original publication in Refuge: Canada's Journal on Refugees is cited. 
Arab-identified mainstream while others identify as Darfurians, or as hailing from the Nuba Mountains. Even after the 2011 secession of South Sudan from the body politic of the Republic of Sudan, a discourse of a nation of Sudan endures in Sudanese constellations of home.

For a decade at the turn of the century, Cairo's ambiguous reception of Sudanese in exile provided the setting for a more volatile homemaking. During a prolonged period of political and legal limbo, exiled Sudanese resided in Cairo in a state of uncertainty, maintained by policies specific to historical Sudanese-Egyptian relations. Notwithstanding their liminal status, Sudanese also came to Cairo for its familiarity while seeking opportunities to travel elsewhere. Cairo in the 1990s was an important border zone, a hub of regional and international movement that offered the possibility for some Sudanese to transform their protracted temporary situation through work visas to Arab Gulf countries or political asylum in the West. While resisting the official Egyptian discourse of a united Nile Valley, home to Egyptians and Sudanese, Egypt's unique domestic policies towards Sudanese undoubtedly shaped their conception of a national Home separate from the Egyptian state.

While making a temporary home in Cairo, Sudanese in my study continued to pursue key cultural activities that maintained their sense of communal identity, many associated with the domestic-women and men cooked and ate familiar Sudanese foods like kisra, weika, and 'asi$i d a$, listened to Sudanese music on cassette players, and pursued Sudanese ideals of beauty through elaborate bodily cleansing, decorating, and perfuming. These practices helped Sudanese to cultivate a private ethnic identity that grounded them in the face of the pressures of exile. But Sudanese in Cairo did not live in exclusively Sudanese neighbourhoods where communal traditions could be easily nurtured and transmitted. On the contrary, the apartments in which Sudanese lived for the years of their exile in Cairo were often far apart, separated by bustling swaths of commercial and residential sprawl. Despite the long and complicated journeys required to move from place to place in Cairo, Sudanese exerted extraordinary efforts to visit each other. Women and men, individually and in groups, often with children in tow, endured crowded and unpleasant conditions across different forms of transportation daily for visits that might last for less time than the journey itself.

These mobile visiting practices knit together far-flung dwellings across unfamiliar urban space into a social fabric visible only to their Sudanese participants. Although Sudanese apartment-dwellers did reproduce homey practices that they thought of as "typically" Sudanese, the domesticity of the dwellings was not the essence of Sudanese homemaking in exile. Rather, homemaking for Sudanese exiles comprised their aggregate acts of visiting, creating a shifting network of people connecting temporary households across urban space through their movements. Theorizing home and homemaking as a product of volatile networks helps us recognize the mobile strategies required to connect people across space and time. Not only did visiting provide social support, domestic comforts, and information for individual visitors and their hosts, it also allowed Sudanese to map a communal home in exile. Through a commitment to maintaining Sudanese community connections in the most difficult of urban settings, Sudanese in Cairo brought together mobile people and temporary places, thus imagining a virtual home that gave meaning to their exilic predicament.

Anita Fábos is an anthropologist who teaches at Clark University. She has engaged with research and praxis among Muslim Arab Sudanese forced migrants in the Middle East, Europe, and the United States. Fábos's work explores transnational ethnic and religious identity, race, displacement, and gender among Muslim refugees at a time of intensifying discourses of "security" and "Islamic spiritual geography." The author may be contacted at afabos@clarku.edu.

\section{Notes}

1 This article began as a conference paper given in 2001 as part of a panel entitled "Urban 'Borderzones': Sudanese Refugees and Forced Migrants in Cairo" at the American Anthropological Association annual meetings. I thank my fellow panellists Carla Daughtry, Stephanie Riak Akuei, and Elizabeth Coker for a memorable session. I am grateful to Catherine Brun for her encouragement to revisit my nascent thinking on liminality, visiting, and home for this issue. David Sims, Diane Singerman, Linda Oldham, Max Rodenbeck, Ian Portman, and Muhammad Abd al-Wadoud influenced my thinking about Cairo's urban space. A note of appreciation for two anonymous reviewers whose suggestions improved the text, although any inaccuracies remain my own responsibility. Finally, I am forever indebted to Amira Ahmed Abderahman for including me in her own visiting network and sharing her remarkable insights with me.

2 Cathrine Brun and Anita Fábos, "Making Homes in Limbo? A Conceptual Framework," this issue.

3 Anita H. Fábos, "Brothers" or Others? Propriety and Gender for Muslim Arab Sudanese in Egypt (Oxford: Berghahn Books, 2010).

4 Brun and Fábos, "Making Homes in Limbo?"

5 Anita H. Fábos and Gaim Kibreab, "Introduction," in "Refugees in Urban Settings of the Global South," special issue, Refuge 24, no. 1 (2007): 1-19; Gaim Kibreab, "Invisible Integration in the Greater Horn Region," in Regional

CAnita Fábos, 2015. This open-access work is licensed under a Creative Commons Attribution-NonCommercial 4.0 International License, which permits use, reproduction and distribution in any medium for non-commercial purposes, provided the original author(s) are credited and the original publication in Refuge: Canada's Journal on Refugees is cited. 
Integration, Identity and Citizenship in the Greater Horn of Africa, ed. Kidane Mengisteab and Redie Bereketeab. Eastern Africa Series, 69-110 (Woodbridge, Suffolk: James Currey, 2012).

6 UNHCR, "Protracted Refugee Situations: The Search for Practical Solutions," in The State of the World's Refugees: Human Displacement in the New Millennium, ed. Nada Merheb and Sean Loughna (Oxford: Oxford University Press, 2006), 107.

7 Kibreab, "Invisible Integration."

8 Victoria Mason, "The Im/Mobilities of Iraqi Refugees in Jordan: Pan-Arabism, 'Hospitality' and the Figure of the 'Refugee,'” Mobilities 6, no. 3 (2011): 355.

9 Oroub El Abed, Unprotected: Palestinians in Egypt since 1948 (Ottawa: Institute for Palestinian Studies / IDRC, 2009).

10 Dereck Cooper, "Urban Refugees: Ethiopians and Eritreans in Cairo," Cairo Papers in Social Science 15, no. 2 (1992): 1-53.

11 Mulki Al-Sharmani, "Living Transnationally: Somali Diasporic Women in Cairo," International Migration 44, no. 1 (2006): 55-77.

12 Philippe Fargues, Saeed El-Masry, Sara Sadek, and Azza Shaban, Iraqis in Egypt: A Statistical Survey in 2008 (Cairo: Center for Migration and Refugee Studies, The American University in Cairo, 2008).

13 Karen Jacobsen, Maysa Ayoub, and Alice Johnson, "Remittances to Transit Countries: The Impact on Sudanese Refugee Livelihoods in Cairo," CMRS Working Papers (2012); Lorraine Currie, "Who Can Be Added': The Effects of Refugee Status Determination and Third Country Resettlement Processes on the Marriage Strategies, Rites, and Customs of the Southern Sudanese in Cairo," Refuge 24, no. 1 (2007): 71-87; Ayman Zohry, "The Place of Egypt in the Regional Migration System as a Receiving Country," Revue européenne des migrations internationales 19, no. 3 (2003): 129-49; Themba Lewis, "Come, We Kill What Is Called 'Persecution Life'": Sudanese Refugee 78 Youth Gangs in Cairo," Oxford Monitor of Forced Migration 1, no. 1 (2011): 78-92; Elizabeth M. Coker, "Dislocated Identity and the Fragmented Body: Discourses of Resistance among Southern Sudanese Refugees in Cairo," Journal of Refugee Studies 17, no. 4 (2004): 401-18; Anita H. Fábos, "Embodying Transition: FGC, Displacement and Gender-Making for Sudanese in Cairo," Feminist Review 69 (2001): 90-110; Pascale Ghazaleh, "Two Miles into Limbo: Displaced Sudanese in a Cairo Slum," Middle East Report 225 (2002 ): 2-7.

14 For example, the Egyptian Constitution, Article 53, states, "The right to political asylum shall be granted by the State to every foreigner persecuted for defending the people's interests, human rights, peace or justice. The extradition of political refugees shall be prohibited."

15 Gabriel Warburg, Historical Discord in the Nile Valley (London: Hurst, 1992).
16 United Nations Security Council resolution 1054, adopted on 26 April 1996, placed sanctions on the Government of Sudan after its failure to comply with OAU requests to extradite suspects sheltered in the country to Ethiopia. Yearbook of the United Nations (New York: United Nations, United Nations Publications, 24 January 2002), 54:218.

17 Sherifa Shafei, Forced Migration Online Expert Guide to Egypt. Forced Migration Online (Oxford: Refugee Studies Centre, University of Oxford, 2004).

18 Olusola Oladapo Makinde, "Urbanization, Housing and Environment: Megacities of Africa," International Journal of Development and Sustainability 1, no. 3 (2012): 976-93.

19 Jackline Wahba, "An Overview of Internal and International Migration in Egypt," in Egypt's Labor Market Revisited, ed. Ragui Assaad, 157-76 (Cairo: American University in Cairo Press, 2009); L. Vignal and E. Denis, "Cairo as Regional-Global Economic Capital?," in Cairo Cosmopolitan: Politics, Culture and Urban Space in the New Globalised Middle East, ed. D. Singerman and P. Amar, 99-151 (Cairo: American University in Cairo Press, 2006); Ayman Zohry, "The Place of Egypt in the Regional Migration System as a Receiving Country." Revue européenne des migrations internationales 19, no. 3 (2003): 129-49.

20 While taking place after this research was conducted, the events of the February 2011 revolution in Egypt and its aftermath have contributed equal measures of hope and alarm to Cairo's urban mix: the exhilaration of ordinary Egyptians taking to the streets to force the military government of Hosny Mubarak to stand down has given way to fear-of political instability and autocratic power, and personal insecurity on the very same streets.

21 For more information, see "Egypt," 2010 Demographic Yearbook (New York: United Nations Statistics Division, Demographic and Social Statistics), http://unstats.un.org/ unsd/pocketbook/PDF/2011/Egypt.pdf.

22 Singerman and Amar, Cairo Cosmopolitan.

23 Some sources suggest that this figure was in the hundreds of thousands, though the evidence is inconclusive.

24 The 1952 Egyptian revolution marked the culmination of nationalism that increasingly required citizens to align with a unified vision of "Egyptianness," a vision that consequently turned many Cairenes into "foreigners" in their own city.

25 Saad Eddin Ibrahim, The Copts of Egypt (Cairo: Ibn Khaldun Center for Development Studies, 1996).

26 Exceptions may be made in the case of non-citizen women who marry Egyptian men.

27 Sudanese territory was administered by a British governor-general under the Anglo-Egyptian Condominium arrangement from 1899 until 1955, even during Egypt's own struggle for independence from British colonial rule. 28 Shafei, Forced Migration.

29 Fábos, "Brothers" or Others?

(C)Anita Fábos, 2015. This open-access work is licensed under a Creative Commons Attribution-NonCommercial 4.0 International License, which permits use, reproduction and distribution in any mediumfor non-commercial purposes, provided the original author(s) are credited and the original publication in Refuge: Canada's Journal on Refugees is cited. 
30 Muneera Salem-Murdoch, Arabs and Nubians in New Halfa: A Study of Settlement and Irrigation (Salt Lake City: University of Utah Press, 1989).

31 Ellen T. Ismail, Social Environment and Daily Routine of Sudanese Women: A Case Study of Urban Middle-Class Housewives (Berlin: Dietrich Reimer Verlag, 1982).

32 Christine Eickelman, "Fertility and Social Change in Oman: Women's Perspectives," Middle East Journal (1993): 652-66.

33 David Sims, Understanding Cairo: The Logic of a City Out of Control (Cairo: American University in Cairo Press, 2011).

34 Following Brun and Fábos, "Making Homes in Limbo?" Home here reflects national longing for the homeland, and is distinguished from both home as dwelling and HOME as the system of nation-states underpinning the refugee regime.
35 Government of Egypt. Foreigners Regulations (Cairo: Middle East Library for Economic Services, 1996).

36 Incense-burning is also a common practice across the Arabian Gulf countries.

37 A thick, highly mucilaginous soup made from the leaves of a type of mallow boiled in (usually) chicken broth.

38 A Muslim reformist movement founded by Ustaz Mahmoud Muhammad Taha and outlawed by the Sudanese regime.

39 A floor-length long-sleeve caftan worn by many Sudanese men.

40 A sari-like modesty garment worn by many Sudanese women; Republican Sisters are often recognizable by their white tobes.

CAnita Fábos, 2015. This open-access work is licensed under a Creative Commons Attribution-NonCommercial 4.0 International License, which permits use, reproduction and distribution in any medium for non-commercial purposes, provided the original author(s) are credited and the original publication in Refuge: Canada's Journal on Refugees is cited. 